\title{
Aeromonas spp. suggested as the causative agents of red spot disease in northern Vietnamese grass carp Ctenopharyngodon idella
}

\author{
Richard Mayrhofer ${ }^{1}$, Simon Menanteau-Ledouble ${ }^{1}$, Johannes Pucher ${ }^{2}$, \\ Ulfert Focken ${ }^{3}$, Mansour El-Matbouli ${ }^{1, *}$ \\ ${ }^{1}$ Clinical Division of Fish Medicine, University of Veterinary Medicine, 1210 Vienna, Austria \\ ${ }^{2}$ Department of Aquaculture Systems and Animal Nutrition in the Tropics and Subtropics, University of Hohenheim, \\ 70593 Stuttgart, Germany \\ ${ }^{3}$ Thünen Institute of Fisheries Ecology, 27572 Bremerhaven, Germany
}

\begin{abstract}
In northern Vietnam, a disease called 'red spot disease' has been causing high morbidity and mortality in populations of farmed grass carp Ctenopharyngodon idella for about 2 decades. The name 'red spot disease' refers to a condition characterised by haemorrhagic lesions, reddening and ulceration of the skin. Eight different bacterial isolates, namely Aeromonas hydrophila, A. sobria, Staphylococcus epidermidis, Vibrio alginolyticus, Pseudomonas fluorescens, P. luteola, Citrobacter freundii and P. putida, were isolated from diseased grass carp and used for experimental infection of the same species. Fish were challenged with the different bacterial isolates both by immersion and intramuscular injection. Different concentrations of bacteria were tested to evaluate their pathogenicity. Injection with $1 \times 10^{5} \mathrm{CFU}$ of $A$. hydrophila and A. sobria resulted in clinical signs identical to those of red spot-diseased grass carp in Vietnam. None of the other bacterial isolates tested caused any morbidity or mortality in fish challenged either intramuscularly $\left(1 \times 10^{6} \mathrm{CFU}\right)$ or by bath immersion $\left.\left(1 \times 10^{6} \text { or } 1 \times 10^{8} \mathrm{CFU} \mathrm{ml}\right)^{-1}\right)$.
\end{abstract}

KEY WORDS: Aetiology $\cdot$ Clinical trial $\cdot$ Skin lesions $\cdot$ Vietnam

\section{INTRODUCTION}

Fish is a traditional dietary staple in Vietnam, and fisheries and aquatic products provide more than $40 \%$ of protein consumed by the Vietnamese (Dao \& Pham 2003). In the Yen Chau region of Son La province, in north-western Vietnam, fish farming is commonly practiced as a source of dietary protein and for cash income, and nearly all households own at least 1 pond (Pucher et al. 2013). The typical pond system is an integrated semi-intensive polyculture. The primary fish species is grass carp Ctenopharyngodon idella, because it is the only species capable of efficiently ingesting and digest-

*Corresponding author: mansour.el-matbouli@vetmeduni.ac.at ing crop leaves, residues and grasses, which are the primary inputs to the pond system (Dongmeza et al. 2009). Additional benefits of this species are its low cost of production, high market price (Pucher et al. 2015), ability to feed on inexpensive plant material and its usefulness in controlling weed growth in aquaculture (Wells et al. 2003, Zhang et al. 2003). Traditional Vietnamese aquaculture is generally a polyculture and involves multiple species, including several species of carp. Since the early 2000s, grass carp populations have been seasonally affected by an emerging disease. The syndrome known as 'red spot disease' (RSD) has had a major economic impact on fish farm

() The authors 2020. Open Access under Creative Commons by Attribution Licence. Use, distribution and reproduction are unrestricted. Authors and original publication must be credited. 
earnings in the Yen Chau region (Van et al. 2002, Steinbronn 2009) and has been associated with mortalities as high as $100 \%$. This disease is characterised by haemorrhagic lesions on the skin of infected fish, and onset of mortality can be rapid. Little information is currently available about this condition, including its definition or aetiology; however, in addition to Aeromonadaceae, several disease agents could plausibly be playing a role. For example, several viruses are known to infect carp and cause comparable clinical signs; this is the case for grass carp haemorrhagic virus (Zhang et al. 2003) as well as several rhabdoviruses (Ahne 1975). Similarly, the oomycete Aphanomyces invadans is able to cause skin lesions and ulcers comparable to that of RSD (Callinan et al. 1995, Majeed et al. 2018). The aim of this work was to investigate the cause of the seasonal grass-carp disease in Yen Chau, Son La Province, Vietnam.

\section{MATERIALS AND METHODS}

\subsection{Sampling, initial isolation and characterisation of bacterial isolates from diseased grass carp}

Reports from farmers and veterinary institutions in the Yen Chau region in north-western Vietnam indicated that the disease peaks twice annually, in March-April and September-October, when it causes high morbidities and mortalities. From 2008 to 2011, our team visited the Yen Chau province 6 times and sampled 197 fish, including 76 diseased grass carp, 50 apparently healthy grass carp and 71 fish from other species (Pucher et al. 2013). Histopathological examinations were performed on the lesion sites as well as the gills, anterior and posterior kidneys, spleens and livers of affected fish. Anterior kidneys and lesion sites were sampled and PCR was performed on these samples using primers for Aphanomyces invadans (Pucher et al. 2013). Moreover, viral cultivation was attempted alongside bacterial cultivation on Columbia agar (COS) (bioMerieux) supplemented with $5 \%$ sheep blood cells, as this medium is suitable for a wide range of microorganisms.

This cultivation led to the isolation of 8 different bacterial isolates. The isolates were cultivated on COS agar at $26^{\circ} \mathrm{C}$ for $24 \mathrm{~h}$ and identified based on bacterial and colony morphology, Gram staining pattern, motility and biochemistry using the API 20NE/STAPH (bioMerieux) gallery and were stored at $-80^{\circ} \mathrm{C}$ until use.

\subsection{Experimental animals}

Grass carp with a total length of $11 \pm 2 \mathrm{~cm}$ were purchased from a commercial fish farm in Germany. After arrival at the Veterinary University of Vienna, the fish were kept in a quarantine tank for $6 \mathrm{wk}$ for acclimatisation. Ten fish were sampled and examined for any visible parasites, and bacteriological (on COS agar) and virological cultures (on common carp brain cells) were attempted from kidney and liver samples to confirm the absence of infection. After all examinations yielded negative results and no morbidity or mortality was observed, the fish were moved to $100 \mathrm{l}$ tanks (10 carp per tank ${ }^{-1}$; each treatment was performed in duplicate for a total of 12 tanks) with an average water temperature of $25 \pm$ $1^{\circ} \mathrm{C}$, an average oxygen level of $6.7 \pm 0.2 \mathrm{mg} \mathrm{ml}^{-1}$, a $\mathrm{pH}$ of $7.5 \pm 0.1$, and a water exchange rate of at least $20 \% \mathrm{~d}^{-1}$. The fish were fed once daily with commercial pellet feed (Garant, 30\% crude protein and 9\% fat), and faeces were removed every $2 \mathrm{~d}$. After the acclimatisation period, fish were brought into contact with the 8 different bacterial isolates.

\subsection{Infection trial}

\subsubsection{Preparation of the bacterial inoculum}

The 8 different isolates of bacteria from diseased grass carp were prepared for the infection trial as follows. The bacteria were grown for $18 \mathrm{~h}$ at $26^{\circ} \mathrm{C}$ in trypticase soy broth (bioMerieux) with shaking, except Staphylococcus epidermidis, for which the temperature was raised to $37^{\circ} \mathrm{C}$. After $18 \mathrm{~h}$ of culture, the suspension was stored at $4^{\circ} \mathrm{C}$ for $24 \mathrm{~h}$. Additionally, $0.1 \mathrm{ml}$ of each suspension was serial diluted and spread in triplicates on COS plates (bioMerieux) containing $5 \%$ sheep blood cells to determine the bacterial concentration by colony counting. After $24 \mathrm{~h}$, the concentration of bacteria from each isolate was calculated. The bacterial cultures were then centrifuged at $9520 \times g$ for $20 \mathrm{~min}$ (Hettich universal 32), the supernatant was removed, and the bacteria were washed twice using sterile $0.9 \% \mathrm{NaCl}$ (Braun); afterwards, they were suspended in sterile $0.9 \% \mathrm{NaCl}$ solution and diluted to the required concentration.

The final bacterial suspensions at either $1 \times 10^{6}$ or $1 \times 10^{8} \mathrm{CFU} \mathrm{ml}{ }^{-1}$ were plated on COS agar in triplicates to confirm the purity of these cultures. The concentration of viable bacteria was confirmed by serial dilution and plating on COS agar plates followed by incubation for $24 \mathrm{~h}$ at either $26^{\circ} \mathrm{C}$ or, in the case of 
S. epidermidis, at $37^{\circ} \mathrm{C}$. Pure cultures were recovered on the plates, CFUs were calculated for each plate, and the corresponding bacterial concentration was calculated.

\subsubsection{Infection procedure}

The pathogenicity of the isolates for grass carp was evaluated using both immersion and intramuscular (i.m.) injection as routes of exposure as well as by using 2 different infection doses (Table 1).

For the immersion route, all bacterial isolates were adjusted to the same density of $1 \times 10^{6} \mathrm{CFU} \mathrm{ml}^{-1}$ and equal volumes from each culture were mixed together. Immediately afterwards, a small area of mucus of approximately $5 \times 1 \mathrm{~cm}$ was removed from the latero-dorsal part of the skin of 2 groups of 10 fish using alcohol-soaked cotton tissues. The fish were then returned to their tanks and the bacterial mixture was added to a final volume of $1 \times 10^{6} \mathrm{CFU} \mathrm{m}^{-1}$ and the fish were kept immersed for $1 \mathrm{~h}$ in the bacterial solution. After exposure, the fish were monitored twice daily for $14 \mathrm{~d}$. When no infection developed from this exposure, this procedure was repeated in the same manner on 10 new fish, using a higher dose of $1 \times 10^{8} \mathrm{CFU} \mathrm{m} \mathrm{m}^{-1}$.

For the injection route, groups of 10 fish each were individually anaesthetized in water containing $0.1 \mathrm{~g} \mathrm{l}^{-1} \mathrm{MS}-222$ (Sigma-Aldrich) and infected by i.m. injection in the dorsal muscle using $0.1 \mathrm{ml}$ of $1 \times$ $10^{6} \mathrm{CFU} \mathrm{ml}^{-1}$ of a pure culture from each of the 8 bacterial isolates. Each group of 10 fish was represented in duplicate in 2 aquaria each, for a total of 20 fish tested for each isolate. This resulted in an infection dose of $1 \times 10^{5} \mathrm{CFU}$, which was chosen because it has been defined as the $\mathrm{LD}_{50}$ of moderately virulent bacterial agents after i.m. injection (Lallier \& Daigneault
1984). For most isolates, with the exception of Aeromonas hydrophila and A. sobria, no infection developed from this exposure. We therefore performed a confirmatory trial using either the same dose of $A$. hydrophila and A. sobria, or a higher dose of $1 \times 10^{7} \mathrm{CFU}$ for the other isolates, in case these other isolates were less virulent (Table 1). In addition, at the time of each of the 3 challenges, 2 sets of 10 fish each were kept under identical conditions and used as negative control groups: the fish were either immersed in a $\mathrm{NaCl}$ solution or injected intramuscularly with a $0.9 \% \mathrm{NaCl}$ solution to mimic the infection route in the challenge. The bacterially challenged fish and the fish from the control groups were observed for $2 \mathrm{wk}$.

Following application of the bacteria, the fish were kept for $14 \mathrm{~d}$ under the same conditions as before to observe the development of clinical signs of the infection. During this period, the fish were monitored twice daily for morbidity and mortality. Fish that showed severe signs of infection were humanely euthanized by prolonged immersion in a $1 \mathrm{~g} \mathrm{l}^{-1}$ solution of MS-222 (SigmaAldrich), and all remaining fish were similarly euthanized at the end of the experiment. Differences in mortality rates between the groups were compared using Fisher's exact test in IBM SPSS Statistics 25 (Microsoft). All dead and euthanized fish were examined for signs of infection by macroscopic investigation and conventional bacteriological analysis of the skin at the injection site (if pertinent), hepatopancreas and posterior kidney by re-isolation on COS agar plates. This isolation was followed by morphological and biochemical identification of bacteria as well as PCR according to the procedure by Dorsch et al. (1994), to confirm their identity and likely involvement in infection.

Table 1. Description of the infection groups and results of the infection; i.m.: intramuscular injection; na: not applicable. p-values compared to control

\begin{tabular}{|lcccc|}
\hline Bacterial species & $\begin{array}{c}\text { Dose } \\
\text { (CFU) }\end{array}$ & $\begin{array}{c}\text { Exposure } \\
\text { method }\end{array}$ & $\begin{array}{c}\text { Mortality } \\
\text { (n/exposed fish) }\end{array}$ & $\begin{array}{c}\text { Clinical signs } \\
\text { (n/exposed fish) }\end{array}$ \\
\hline $\begin{array}{l}\text { Staphylococcus epidermidis, Vibrio alginolyticus, } \\
\text { Pseudomonas putida, P. fluorescens }\end{array}$ & $1 \times 10^{5}$ & i.m. & $0 / 10$ & $0 / 10$ \\
$\begin{array}{l}\text { P. luteola, Citrobacter freundii } \\
\text { S. epidermidis, V. alginolyticus, P. putida, }\end{array}$ & $1 \times 10^{8}$ & i.m. & $0 / 10$ & 1 \\
P. fluorescens, P. luteola, C. freundii & $1 \times 10^{5}$ & i.m. & $3 / 20$ & $0 / 10$ \\
Aeromonas hydrophila & $1 \times 10^{5}$ & i.m. & $10 / 20$ & $3 / 20$ \\
A. sobria & $1 \times 10^{6} \mathrm{ml}^{-1}, 1 \times 10^{8} \mathrm{ml}^{-1}$ & Bath & $0 / 10$ & 0.2308 \\
Bacterial mix & na & na & $0 / 20$ & $0 / 10$ \\
Control groups & & & 0.0004 \\
\end{tabular}




\section{RESULTS}

Preliminary investigation showed the presence of bacterial aggregation on the fish epidermis (Mayrhofer et al. 2011). No viruses could be isolated from any of the sampled fish (Pucher et al. 2013). Furthermore, the PCR did not detect the presence of Aphanomyces invadans. On the other hand, 8 different bacterial species were isolated from diseased fish: Aeromonas hydrophila, A. sobria, Staphylococcus epidermidis, Vibrio alginolyticus, Pseudomonas fluorescens, P. luteola, Citrobacter freundii and P. putida. All of these species are known to be pathogenic for fish and could plausibly act as the causative agents of the RSD in Vietnam.

When an infection trial was performed to test these various bacterial agents, we found that the 2 Aeromonas isolates (A. hydrophila and A. sobria) caused a visible bacterial infection in the fish, but only when infection was performed using i.m. injection rather than immersion. These clinical signs included reddening, haemorrhagic changes and ulceration of skin at the injection site (Fig. 1A,B) and loss of scales consistent with that reported for the RSD of grass carp in northern Vietnam (Fig. 1C,D). The only recorded mortalities occurred in the fish challenged with either A. hydrophila or A. sobria, and all fish that developed visible clinical signs succumbed to the disease. A. hydrophila was associated with lower mortalities than A. sobria (15 and $50 \%$, respectively, Table 1 ), but the difference between these 2 isolates was not statistically significant $(\mathrm{p}=0.0958)$. Only the mortalities in the fish infected with $A$. sobria were significantly different from the control $(\mathrm{p}=0.0004)$, while the mortalities in the fish infected with $A$. hydrophila were not $(p=0.2308)$. The other 6 bacterial species caused no clinical signs in grass carp after i.m. injection of $1 \times 10^{5} \mathrm{CFU}$ of bacteria or in either concentration $\left(1 \times 10^{6}\right.$ or $1 \times 10^{8} \mathrm{CFU}$ $\mathrm{ml}^{-1}$ ) of the bath challenge. These fish did not develop external lesions, and bacteriological re-isolation from the internal organs was unsuccessful. The bacteria could be re-isolated from the skin, hepatopancreas and posterior kidney of all the fish that had succumbed to the infection (Table 2).
Moreover, for 1 fish infected with $P$. fluorescens, bacteria could be re-isolated from the hepatopancreas and posterior kidney $14 \mathrm{~d}$ after i.m. injection with $1 \times 10^{5} \mathrm{CFU}$ of the bacterium. Similarly, in 2 instances, A. hydrophila could be re-isolated from the hepatopancreas and posterior kidney from 2 apparently healthy fish. Interestingly, all 3 of these fish lacked clinical signs of infection, and in none of these cases could the bacteria be re-isolated from the injection site.

\section{DISCUSSION}

With the exception of the Aeromonas hydrophila or A. sobria isolates, none of the bacteria reproduced the disease in infected fish, regardless of the method of infection. For A. hydrophila and A. so-

Table 2. Re-isolation of bacteria from the fish injected intramuscularly with $1 \times 10^{5} \mathrm{CFU}$ of the same bacteria; 20 fish were injected with each isolate

\begin{tabular}{|lccc|}
\hline \multirow{2}{*}{ Infection group } & \multicolumn{3}{c|}{ Re-isolation } \\
\cline { 2 - 4 } & Skin & $\begin{array}{c}\text { Hepato- } \\
\text { pancreas }\end{array}$ & $\begin{array}{c}\text { Posterior } \\
\text { kidney }\end{array}$ \\
\hline Aeromonas hydrophila & $3 / 20$ & $5 / 20$ & $5 / 20$ \\
A. sobria & $10 / 20$ & $10 / 20$ & $10 / 20$ \\
Pseudomonas fluorescens & $0 / 20$ & $1 / 20$ & $1 / 20$ \\
\hline
\end{tabular}
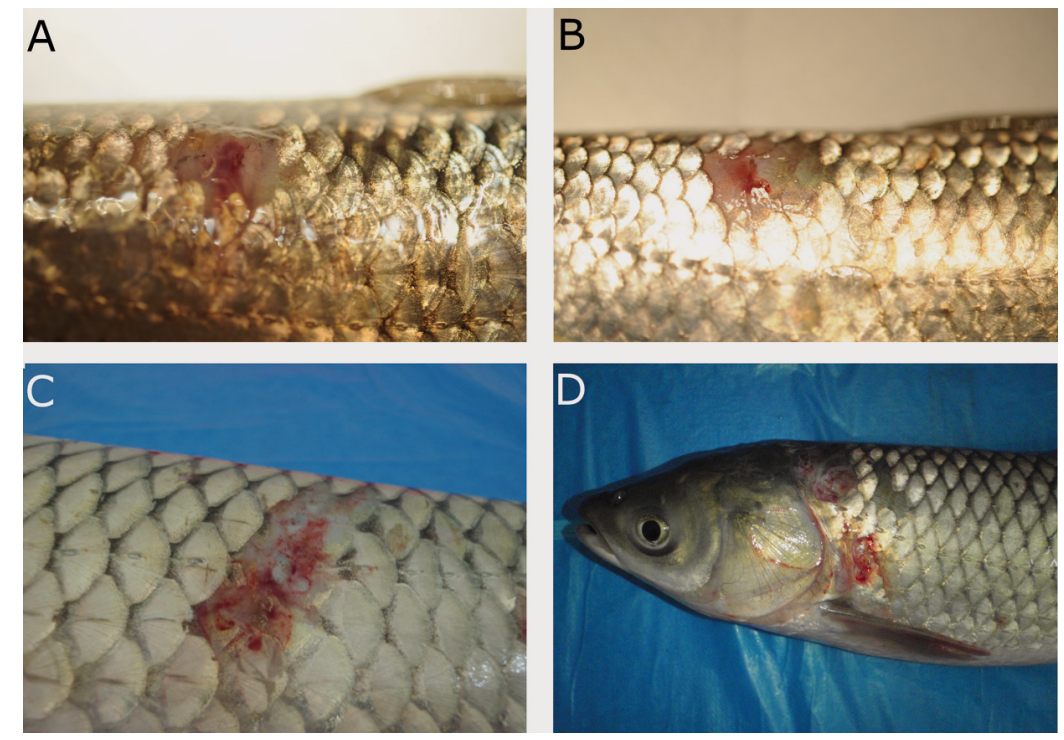

Fig. 1. Clinical signs observed on grass carp infected with Aeromonas hydrophila. $(\mathrm{A}, \mathrm{B})$ Skin lesions following experimental infection by intramuscular injection. $\left(C_{1} D\right)$ Haemorrhagic skin lesions in naturally infected grass carp in Vietnam 
bria, artificial i.m. infection with pure cultures of either isolate originating from RSD-infected grass carp in northern Vietnam resulted in an acute infection of the fish as well as clinical signs consistent with this disease (Van et al. 2002): skin lesions, followed by septicaemia and acute mortality. On the other hand, infection by immersion did not reproduce the disease. Notably, the difficulty to reliably induce disease through routes of entry beside injection is well documented in multiple fish species, including cyprinids, for motile Aeromonas, in particular for A. hydrophila, which is the most studied of the motile Aeromonas (Das Mahapatra et al. 2008, Sarker \& Faruk 2016, Zhang et al. 2016, Peatman et al. 2018).

The fact that i.m. injection was able to reproduce the disease while immersion was not also suggests that both Aeromonas strains act as opportunistic invaders that need predisposing factors like damage of the epithelial membrane. Fish bacterial pathogens can take advantage of sites of abrasion on the skin as sites of attachment (Menanteau-Ledouble et al. 2011). A plausible hypothesis would be that damage of the epithelium caused by external parasites provides a portal of entry for these bacteria and, indeed, different parasites like monogenean trematodes (Dactylogyrus and Gyrodactylus spp.), ciliates (Trichodina and Ichthyophthirius spp.) and copepods (Lernaea sp.) known to damage the skin of their host have been reported from the research area (Pucher et al. 2013). Handling of the fish could also damage the skin and predispose them to bacterial infections. For example, a common practice in the research area of northern Vietnam is to catch fish for home consumption by using casting nets. Grass carp are more often caught and released than other cohabitated fish species for several reasons: grass carp are mainly stocked for cash income and not for home consumption (Steinbronn 2009), which means that they are more likely to be released when accidentally caught. Moreover, grass carp are the main species stocked in the earthen ponds (Steinbronn 2009), and their uncommon habit to try to escape by jumping out of water results in a higher chance to catch them by using a casting net, compared to most other fish species that attempt to escape by submerging to the bottom.

Interestingly, both of the species of Aeromonas tested were able to reproduce the disease and the associated clinical signs. Moreover, in 2 cases, A. hydrophila could be re-isolated from the internal organs even as the fish did not appear sick or present signs of infection, which suggests that both of these bacteria might have been able to establish sub-clinical infections in the fish.

A. hydrophila is a ubiquitous, Gram-negative bacterium that possesses many different virulence factors, and the pathogenesis of infection is complex and multifactorial (Rasmussen-Ivey et al. 2016). This bacterium can cause high morbidity and mortality among grass carp (Uzbilek \& Yildiz 2002), and it can cause haemorrhagic changes and ulceration of skin as well as systemic septicaemia in infected fish. Other known signs of infection are the loss of scales, necrosis of fins and ascites, consistent with what is observed in the case of RSD. The course of infection can range from acute to chronic (Inglis et al. 1993). A. sobria is another member of the family Aeromonadaceae. A. sobria presents many similarities with other virulent members of the genus Aeromonas, including the fish pathogens $A$. hydrophila and $A$. salmonicida. A. sobria is described as a primary pathogen for European perch Perca fluviatilis, causing focal skin lesions, fin rot and mortality, and it also causes haemorrhagic changes on the skin of common carp Cyprinus carpio (Wahli et al. 2005, Kozińska 2007). In addition, A. sobria can cause haemorrhages, skin lesions and mortality in the fish Garra rufa, a species increasingly used in pedicure treatment (Majtán et al. 2012).

A. hydrophila and A. sobria are related species that share several virulence factors. Therefore, it is not surprising that these bacteria would cause similar clinical signs and be regarded as the same disease. The family Aeromonadaceae is a large family that includes several fish pathogens associated with similar clinical signs; therefore, it is plausible that other thermophilic Aeromonas might also contribute to outbreaks of the disease. Because these species are similar to an extent and because they would be treated in the same way, this distinction is currently somewhat academic.

The contact of fish with the mixture of all bacterial isolates following removal of the mucus did not result in clinical signs or morbidity of the fish at either concentration. Furthermore, no bacteria could be reisolated from the fish exposed to immersion bath or from control fish at the end of the trial, suggesting that none of the isolates tested, with the exception of A. hydrophila and A. sobria, was virulent.

In general, bacterial isolates are grouped as weakly virulent and avirulent when causing disease after injection of a concentration of $1 \times 10^{5.5}$ and $1 \times$ $10^{8} \mathrm{CFU}$, respectively (Lallier \& Daigneault 1984), while virulent isolates only require doses of $1 \times 10^{4.5}$. Therefore, these isolates of A. hydrophila and A. so- 
bria could be considered to be weakly or moderately virulent, and all other isolates used are considered to be avirulent for grass carp. Improving the water quality by changing pond management (Pucher et al. 2016), improving the feed base and feed quality (Pucher et al. 2014b, 2015, Pucher \& Focken 2017) and reducing potential stressors like pesticide-contaminated feeds (Pucher et al. 2014a) are advised to reduce the susceptibility of grass carp against these weakly virulent bacteria.

Similarly, the disease has been mostly reported in March-April and September-October, periods that correspond to the beginning and end of the rainy seasons in Vietnam, when heavy rainfall is common. This suggests that washing of agrochemical and eroded soil particles as well as loss of water quality following the heavy rains might act as a stressor and a contributing factor in the development of the disease. This is consistent with the fact that fish mortalities have often been observed directly after other occurrences of heavy rain (Steinbronn 2009).

\section{CONCLUSION}

In this challenge, we were able to reproduce the clinical signs associated with outbreaks of RSD, including reddening and haemorrhagic changes at the injection site, ulceration and loss of scales. In all instances, the appearance of these clinical signs was followed by death of the infected fish, and the bacteria could be re-isolated from the internal organs, showing that the infection had become systemic.

Of the 8 different bacterial isolates isolated from fish displaying clinical signs of RSD in northern Vietnam, 2 isolates belonging to the genus Aeromonas (A. hydrophila and A. sobria) were able to reproduce the disease. Intramuscular injection with $1 \times 10^{5} \mathrm{CFU}$ of either of these bacteria caused mortality in the infected fish and reproduced the clinical signs associated with the disease. Moreover, the bacteria could be re-isolated from the infected fish, fulfilling Koch's postulates. Therefore, our results suggest that the disease known as RSD affecting grass carp in northern Vietnam is caused by infection with members of the bacterial genus Aeromonas.

Acknowledgements. This study was funded by the Austrian Science Fund (FWF) grant no. P28837-B22 and the Deutsche Forschungsgemeinschaft (DFG) under the umbrella of the Uplands Program (SFB 564). Neither of these funding bodies played a role in the design or conclusion of the study. The study was approved by the institutional ethics committee and the national authority according to the Law for Animal Experiments (Tierversuchsgesetz) under No GZ 68.205/ 0086-II/3b/2012.

\section{LITERATURE CITED}

Ahne W (1975) A rhabdovirus isolated from grass carp (Ctenopharyngodon idella Val.). Arch Virol 48:181-185

Callinan RB, Paclibare JO, Bondad-Reantaso MG, Chin JC, Gogolewski RP (1995) Aphanomyces species associated with epizootic ulcerative syndrome (EUS) in the Philippines and red spot disease (RSD) in Australia: preliminary comparative studies. Dis Aquat Org 21:233-238

Dao MS, Pham T (2003) Management of coastal fisheries in Vietnam. In: Silvestre G, Garces L, Stobutzki I, Ahmed M and others (eds) WorldFish Center Conference Proceedings. Assessment, management and future directions for coastal fisheries in Asian countries. WorldFish Center and Asian Development Bank, Penang, p 957-986

* Das Mahapatra K, Gjerde B, Sahoo PK, Saha JN and others (2008) Genetic variations in survival of rohu carp (Labeo rohita, Hamilton) after Aeromonas hydrophila infection in challenge tests. Aquaculture 279:29-34

Dongmeza EB, Steinbronn S, Francis G, Focken U, Becker K (2009) Investigations on the nutrient and antinutrient content of typical plants used as fish feed in small scale aquaculture in the mountainous regions of Northern Vietnam. Anim Feed Sci Technol 149:162-178

* Dorsch M, Ashbolt NJ, Cox PT, Goodman AE (1994) Rapid identification of Aeromonas species using 16S rDNA targeted oligonucleotide primers: a molecular approach based on screening of environmental isolates. J Appl Bacteriol 77:722-726

Inglis V, Roberts RJ, Bromage NR (1993) Motile aeromonad septicaemia. In: Inglis V, Roberts RJ, Bromage NR (eds) Bacterial diseases of fish. Wiley-Blackwell, Oxford, p 143-156

Kozińska A (2007) Dominant pathogenic species of mesophilic aeromonads isolated from diseased and healthy fish cultured in Poland. J Fish Dis 30:293-301

* Lallier R, Daigneault P (1984) Antigenic differentiation of pili from non-virulent and fish-pathogenic strains of Aeromonas hydrophila. J Fish Dis 7:509-512

Majeed M, Saleh M, Menanteau-Ledouble S, Palić D, ElMatbouli M (2018) Dissemination, identification and treatment of Aphanomyces invadans, the causative agent of epizootic ulcerative syndrome in fish. Wien Tierarztl Monatsschr 105:63-71

* Majtán J, Černy J, Ofúkaná A, Takáč P, Kozánek M (2012) Mortality of therapeutic fish Garra rufa caused by Aeromonas sobria. Asian Pac J Trop Biomed 2:85-87

Mayrhofer R, Soliman H, Pucher J, Focken U, El-Matbouli M (2011) Grass carp mortality in northern Vietnam - investigations from 2008-2010. In: $15^{\text {th }}$ International Conference on Diseases of Fish and Shellfish. European Association of Fish Pathologists, Split, p 98

Menanteau-Ledouble S, Karsi A, Lawrence ML (2011) Importance of skin abrasion as a primary site of adhesion for Edwardsiella ictaluri and impact on invasion and systematic infection in channel catfish Ictalurus punctatus. Vet Microbiol 148:425-430

*Peatman E, Mohammed H, Kirby A, Shoemaker CA, Yildirim-Aksoy M, Beck BH (2018) Mechanisms of patho- 
gen virulence and host susceptibility in virulent Aeromonas hydrophila infections of channel catfish (Ictalurus punctatus). Aquaculture 482:1-8

Pucher J, Focken U (2017) Uptake of nitrogen from natural food into fish in differently managed polyculture ponds using ${ }^{15} \mathrm{~N}$ as tracer. Aquacult Int 25:87-105

Pucher J, Steinbronn S, Mayrhofer R, Schad I, El-Matbouli M, Focken U (2013) Improved sustainable aquaculture systems for small-scale farmers in northern Vietnam. In: Fröhlich HL, Schreinemachers P, Stahr K, Clemens G (eds) Mountain research and development. Springer, Berlin, p 76-77

Pucher J, Gut T, Mayrhofer R, El-Matbouli M and others (2014a) Pesticide-contaminated feeds in integrated grass carp aquaculture: toxicology and bioaccumulation. Dis Aquat Org 108:137-147

* Pucher J, Mayrhofer R, El-Matbouli M, Focken U (2014b) ${ }^{15} \mathrm{~N}$ tracer application to evaluate nitrogen dynamics of food webs in two subtropical small-scale aquaculture ponds under different managements. Isotopes Environ Health Stud 50:428-441

* Pucher J, Mayrhofer R, El-Matbouli M, Focken U (2015) Pond management strategies for small-scale aquaculture in northern Vietnam: fish production and economic performance. Aquacult Int 23:297-314

Pucher J, Mayrhofer R, El-Matbouli M, Focken U (2016) Effects of modified pond management on limnological parameters in small-scale aquaculture ponds in mountainous Northern Vietnam. Aquacult Res 47:56-70

Rasmussen-Ivey CR, Figueras MJ, McGarey D, Liles MR (2016) Virulence factors of Aeromonas hydrophila: in the wake of reclassification. Front Microbiol 7:1337

Editorial responsibility: David Verner-Jeffreys, Weymouth, UK
Sarker J, Faruk M (2016) Experimental infection of Aeromonas hydrophila in pangasius. Prog Agric 27:392-399

Steinbronn S (2009) A case study: fish production in the integrated farming system of the Black Thai in Yen Chau district (Son La province) in mountainous north-western Vietnam - current state and potential. PhD dissertation, University of Hohenheim

Uzbilek MK, Yildiz HY (2002) A report on spontaneous diseases in the culture of grass carp (Ctenopharyngodon idella Val. 1844), Turkey. Turk J Vet Anim Sci 26: 407-410

Van PT, Khoa LV, Lua DT, Van KV, Ha NT (2002) The impacts of red spot disease on small-scale aquaculture in northern Vietnam. In: Arthur JR, Phillips MJ, Subasinghe RP, Reantaso MB, MacRae I (eds) Primary aquatic animal health care in rural, small-scale, aquaculture development. Fish Tech Pap 406. FAO, Rome, p 165-176

WWahli T, Burr SE, Pugovkin D, Mueller O, Frey J (2005) Aeromonas sobria, a causative agent of disease in farmed perch, Perca fluviatilis L. J Fish Dis 28:141-150

WWells RDS, Bannon HJ, Hicks BJ (2003) Control of macrophytes by grass carp (Ctenopharyngodon idella) in a Waikato drain, New Zealand. N Z J Mar Freshw Res 37: 85-93

Zhang Q, Ruan H, Li Z, Zhang J, Gui J (2003) Detection of grass carp hemorrhage virus (GCHV) from Vietnam and comparison with GCHV strain from China. High Technol Lett 9:7-13

Zhang D, Xu DH, Shoemaker C (2016) Experimental induction of motile Aeromonas septicemia in channel catfish (Ictalurus punctatus) by waterborne challenge with virulent Aeromonas hydrophila. Aquacult Rep 3:18-23

Submitted: October 7, 2019; Accepted: March 25, 2020

Proofs received from author(s): April 27, 2020 